\title{
On the role of syncretism in finiteness marking for verb second in diachrony and acquisition ${ }^{1}$
}

\author{
Anne Mette Nyvad \\ Aarhus University
}

\begin{abstract}
This paper explores the long-debated interaction between inflectional morphology and syntactic verb movement, more specifically the role of morphological finiteness marking in the presence vs. absence of V2-structures in English, Danish and French. It will be argued that the cross-linguistic variation found in these languages may be accounted for by viewing finiteness as a feature that cuts across tense, mood and agreement, following Eide (2016). Whereas the productive morphological rule generating regular verb forms in English collapses the finiteness distinction, this type of syncretism is not found in Danish and French, and this appears to have major consequences in diachrony, language variation and language acquisition.
\end{abstract}

\section{Introduction}

In traditional generative accounts of verb placement, syntacticians have argued that morphological markings on the finite verb are tightly connected to its ability to undergo syntactic movement operations. In one of the strongest instantiations of the Rich Agreement Hypothesis, a causal and bidirectional relation between agreement marking and $\mathrm{V}^{\circ}$-to$\mathrm{I}^{\circ}$-movement is hypothesized (Rohrbacher 1999). In a similar vein, Vikner (1997: 190) argues that “there is a link between the 'strength' of verbal inflectional morphology and the obligatory movement of the finite verb

1 A special thank you to Sten Vikner, without whom my life would have been very different and not filled with the daily joy of having found the seemingly endless source of intellectual inquiry and thrilling discoveries that is linguistics. The research presented here was funded by the Danish Council for Independent Research, DFF (grant ID: DFF6107-00190).

Ken Ramshøj Christensen, Henrik Jørgensen \& Johanna L. Wood (eds.). 2019.

The Sign of the V-Papers in Honour of Sten Vikner. Dept. of English, School of Communication \& Culture, Aarhus University, pp. 467-487, doi:10.7146/aul.348.109. (C) The author(s). 
to $\mathrm{I}^{\mathrm{o}}$ " and that "[a]n SVO-language has $\mathrm{V}^{\circ}$-to- $\mathrm{I}^{\circ}$ movement [iff] person morphology is found in all tenses" (see also Bobaljik \& Thrainsson 1998). However, in more recent years, the Rich Agreement Hypothesis has been challenged on the basis of empirical data from languages, such as Icelandic and Älvdalen Swedish, which appear to be exceptions to the proposed generalization (e.g. Wiklund et al. 2007 and Garbacz 2010). In addition, as suggested by the mutual exclusivity between $\mathrm{V}^{\circ}$-to- $\mathrm{I}^{\circ}$-movement and Verb Second (henceforth V2), the trigger for the latter appears to hinge upon an independent factor (see e.g. Vikner 1995; Rizzi 1996).

Through a comparative analysis of morphological differences between English, Danish and French, this paper will argue that V2-movement is triggered by a morphological finiteness feature in $\mathrm{C}^{\circ}$, which is tied to synchronic and diachronic syntactic verb movement patterns. It will be argued that e.g. V2 phenomena in diachrony, language variation, and language acquisition in these three languages cannot be accounted for with reference to tense, mood or agreement markings, not least due to the fact that Danish and English are quite parallel in terms of the morphological leveling that has taken place in the verb inflectional paradigms. Instead, following Eide (2016), it will be proposed that the loss of a productive morphological finiteness distinction due to syncretism is at the heart of (i) the loss of V2 in English, (ii) the collapse of preterit and participle forms in English varieties, and (iii) the fact that, unlike their French and Danish peers, English-speaking children produce non-finite $w h$-questions around the age of two. The motivation for the claim that morphological finiteness (i.e. the distinction encoding a paradigmatic opposition between overtly finite and non-finite forms in Danish and French, but not in English) plays a major role in the synchronic dimension is thus offered (sections 2.1-2.3), before the focus turns to hypothesized corollaries in diachrony (section 2.4), language variation (section 2.5) and language acquisition (section 3).

\subsection{Vo-to-Iㅇ-movement}

Modern varieties of English, Danish and French differ in terms of verb movement in two major respects: Presence versus absence of $\mathrm{V}^{\circ}$-to- $\mathrm{I}^{\circ}$ movement in embedded clauses on the one hand and $\mathrm{V}^{\circ}-\mathrm{I}^{\circ}-\mathrm{C}^{\circ}$-movement in main clauses on the other. The former type of movement is said to have taken place when the finite verb (believed to be base-generated in $\mathrm{V}^{\circ}$ ) appears to the left of a sentence-medial adverbial or negation, as in French main and embedded clauses, e.g. (1a). English and Danish, on the 
other hand, are not thought to have $\mathrm{V}^{\circ}$-to- $\mathrm{I}^{\circ}$-movement, (1b) and (1c), in embedded clauses, as the finite main verb stays to the right of the sentencemedial adverbial:

a. French

Que Pierre *souvent mange / mange souvent

That Pierre often eats / eats often

la même chose au déjeuner (ne surprend plus

the same thing at lunch NEG surprises more

personne).

no.one

'That Pierre often eats the same thing at lunch (no longer surprises anyone).'

b. English

That Peter often eats/*eats often the same thing at lunch (no longer surprises anyone).

c. Danish

At Sten ofte spiser / *spiser ofte

That Sten often eats / eats often

det samme til frokost (overrasker ikke længere nogen).

the same at lunch surprises not longer anyone

'That Sten often eats the same thing at lunch (no longer surprises anyone).'

While Present-Day Danish (PDD) and Present-Day English (PDE) are assumed no longer to have $\mathrm{V}^{\circ}$-to- $\mathrm{I}^{\circ}$-movement in embedded clauses, they both did at earlier stages, cf. examples (2) and (3), but by the end of the $1500 \mathrm{~s}$, this type of verb movement was no longer required, (4) and (5):

(2) Middle Danish (Uldaler \& Wellejus 1968: 54, cited by Vikner 2004: 384) tha bøtæ han bondæn tolf øræ foræ then pays he peasant-DEF twelve ore therefore 
um thrællæn takær ey atær gen

if servant.DEF takes not back again

'Then he pays the peasant twelve øre ( $\approx$ pennies) if the servant does not fight back'

(c. 1300, Valdemars sjoellandske lov, yngre redaktion, ch. 86)

(3) Middle English (Davis 1971: 164)

... and he swore that he talkyd neuer wyth no man

... and he swore that he talked never with no man (1460, William Paston I, Letter to John Paston I)

(4) Early Modern Danish (Ruus et al. 2001: 215, cited by Vikner 2004: 384)

Som en Spyflue icke springer vdi den gryde As a blowfly not jumps into the pot

som er hed, men flyer derfra

that is hot but flees therefrom

'As a blowfly does not jump into the pot that is hot, but flees from there'

(1572, Niels Hemmingsen, Om Ecteskab)

(5) Early Modern English (Roberts 2007: 353)

Or if there were, it not belongs to you

(1600, William Shakespeare, Henry IV, IV, i, 98)

Arguing for a version of the Rich Agreement Hypothesis, Vikner (1997, 1999 , inter alia) suggests that $\mathrm{V}^{\circ}$-to- $\mathrm{I}^{\circ}$ movement is connected to person agreement in all tenses, cross-linguistically. In Middle Danish, the plural ending - $c e$ was syncretic with the infinitive, while the singular, -cer (cf. (2) above), had a distinct morphological suffix until the latter generalized to the plural (Vikner 1997: 194) and simply became a morphological marker for tense, or, crucially for the present purposes, finiteness. According to Bertelsen (1905: 95-97, 171-172), the loss of person agreement on regular verbs happened already around 1350 (see Vikner 1997 for more details), but the erosion was presumably not completed for irregular verbs until around the transition between Late Middle Danish and Early Modern Danish, i.e. circa 1500 (Brøndum-Nielsen 1974: 277). Similarly, Roberts 
(1993: 302) asserts that English lost $\mathrm{V}^{\circ}$-to- $\mathrm{I}^{\circ}$ movement "around 1575", while the Early Modern English inflectional system had taken over at the beginning of the $16^{\text {th }}$ century.

These data thus suggest that morphological leveling preceded, and may have triggered, a syntactic change in the option of $\mathrm{V}^{\circ}$-to- $\mathrm{I}^{\circ}$ movement in Danish and English. French still has distinctions in person agreement in all tenses and the fact that this language has retained $\mathrm{V}^{\circ}$-to- $\mathrm{I}^{\circ}$ movement is thus predicted by the account in Vikner (1997, 1999). However, verb movement in main clauses in Danish, English and French cannot be explained with reference to person agreement distinctions in all tenses, as present-day varieties of French and English pattern together (and counter to Danish) in this instance, as we will see now.

\subsection{Verb Second (V2)}

Unlike in PDE, lexical verbs were able to move out of VP in Old English, (7), and Middle English, (8). In fact, they were able to move all the way to $\mathrm{C}^{\circ}$ in declarative main clauses, as was the case in Middle French, (6). This syntactic verb movement operation still applies in main clauses in Danish, (9):

(6) Middle French (Lemieux \& Dupuis 1995: 81)

[Longtemps] fu ly roys Ellnas en la Montaigne [For a long time] was the king Elinas on the mountain 'King Elinas was on the mountain for a long time' (ca. 1390, Jean d'Arras, Mélusine, p. 14)

(7) Old English

[Pas ðreo ðing] forgifo God his gecorenum These three things gives God his chosen 'God gives these three things to his chosen people'

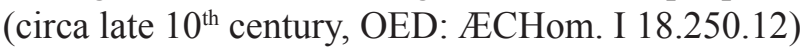

(8) Middle English

[Yet] saw I nevere, by my fader kyn... Yet saw I never, by my father's kin... (1380, Geoffrey Chaucer, The Reeve's Tale, line 184) 


\section{(9) Present-Day Danish}

[Den her sofa] er der ingen, der kan få mig ud af. This here sofa is there nobody who can get me out of 'Nobody's going to get me out of this sofa.'

This phenomenon is known as Verb Second (V2), because the finite verb is found in the second position (i.e. as the second constituent) of the clause, as the result of $\mathrm{V}^{\circ}-\mathrm{I}^{\circ}-\mathrm{C}^{\circ}$-movement (see Schwartz \& Vikner 1996). Even though Danish no longer has $\mathrm{V}^{\circ}$-to- $\mathrm{I}^{\circ}$ movement in embedded clauses, the finite verb systematically undergoes $\mathrm{V}^{\circ}-\mathrm{I}^{\circ}-\mathrm{C}^{\circ}$-movement in declarative main clauses, cf. (9), unlike in English and French. The latter two languages no longer have generalized V2, but rather so-called "residual V2" (Rizzi 1996), as a finite verb moves to $C^{\circ}$ in questions, inverting with the subject in IP-Spec, as in (10):

a. French

[Quel fromage] a-t-il mangé? / [Que] mange-t-il?

Which cheese has-Ø-he eaten? / What eats-Ø-he?

b. English

[Which cheese] has he eaten?/[What] does he eat?

\section{c. Danish}

[Hvaffor'n ost] har han spist? / [Hvad] spiser han? What.for.one cheese has he eaten? / What eats he?

McWhorter (2005: 287) asserts that there appears to be a general consensus that V2 was a Proto-Germanic feature. Generalized V2 eroded around the $15^{\text {th }}$ century in English (Roberts 2007: 58) and the $16^{\text {th }}$ century in French (Roberts 2007: 331; Yang 2000), when the V2 cue $\left[_{\mathrm{CP}} \mathrm{XP}\left[\mathrm{C}_{\mathrm{C}^{\circ}} \mathrm{V}\right]\right]$ (cf. Lightfoot 2006) became facultative for children acquiring language. This paper will argue that the loss of V2 happened for different reasons in English and French, but that changes in verb morphology was ultimately the trigger in both instances. Given that the timing of the loss of generalized $\mathrm{V} 2$ in English appears to roughly coincide with the demise of $\mathrm{V}^{\circ}$-to- $\mathrm{I}^{\circ}$ 
movement, one might prima facie assume that the same trigger may be at the root of these changes in the recorded history of English. However, this paper will argue that while distinctions in agreement morphology may well be at the heart of $\mathrm{V}^{\circ}$-to- $\mathrm{I}^{\circ}$ movement phenomena, V2 is tied to the notion of morphological finiteness, which will now be outlined.

\section{The interaction between morphology and syntactic movement} Lasser (1997: 77) proposed the term $\mathrm{M}$ (orphological)-finiteness as a means of emphasizing the morphosyntactic nature of finiteness, i.e. "the overt form that finiteness takes", as a contrast to the semantico-pragmatic, "invisible function that finiteness serves". This paper follows Eide's (2016) observation that while PDE still marks finiteness morphologically on auxiliaries, it no longer productively applies the finiteness distinction on lexical verbs, and relates it to specific syntactic traits - more specifically, to differences in patterns of verb movement to $\mathrm{C}^{\circ}$ between English, Danish, and French.

\subsection{Morphological finiteness}

Traditionally, finiteness has been thought of as tense and agreement, but this paper will follow Eide (2016: 149) in not considering agreement part of finiteness in the Germanic languages. In general, there has been an impoverishment in the inflectional paradigms of English and Danish (and, to a lesser extent, French), as specific morphosyntactic features have been deleted, but not in parallel fashion: Even though the inflectional paradigm of Danish verbs, in comparison to that of e.g. French (see Vikner 1997 for details), is poor in terms of person and number agreement, given that there is no morphological marking on the verb distinguishing these features, the verb forms are still overtly finite in Danish and the other Mainland Scandinavian languages, cf. Table 1 below. The situation is quite different in English where "all distinctions [...] have been declining for the past thousand years" (Pinker 2000: 87). In OE and ME, however, any verb form still productively encoded $[ \pm$ Past $]$ and $[ \pm$ Finite $]$ morphologically, as in Present-Day Danish: 


\begin{tabular}{|c|c|c|}
\hline & +Finite & - Finite \\
\hline $\begin{array}{l}\text { +Past } \\
\text { Old English: } \\
\text { Middle English: } \\
\text { Present-Day Danish: }\end{array}$ & $\begin{array}{l}\text { Preterit: } \\
\text { healp, hōlde } \\
\text { holp, helede } \\
\text { hjalp, helede }\end{array}$ & $\begin{array}{l}\text { Participle: } \\
\text { holpen, hōed } \\
\text { (y)holpen,, (y)heled } \\
\text { hjulpet, helet }\end{array}$ \\
\hline $\begin{array}{l}\text { - Past } \\
\text { Old English: } \\
\text { Middle English: } \\
\text { Present-Day Danish: }\end{array}$ & $\begin{array}{l}\text { Present: } \\
\text { helpe, hōle } \\
\text { helpe, hele } \\
\text { hjcelper, heler }\end{array}$ & $\begin{array}{l}\text { Infinitive: } \\
\text { helpan, hōelan } \\
\text { helpen, helen } \\
\text { hjcelpe, hele }\end{array}$ \\
\hline
\end{tabular}

Table 1: Morphological finiteness marking in OE, ME and PDD for the PDE verbs "help" and "heal", respectively.

Old English and Middle English had distinct forms in all four cells of the paradigm, both in strong verbs like helpan and weak verbs such as hēlan. That the strong verb helpan has become regular in PDE (help, helped, helped) is yet another indication of the morphological leveling that has taken place. ${ }^{2}$ However, the morphological finiteness distinction is no longer productive in PDE. Here, a verb like heal or healed out of context only signals the $[ \pm$ Past] distinction and not the [ \pm Finite] one (cf. Eide 2016: 146-147). PDE expresses person and number agreement on lexical verbs with 3PSg $-s$ in the present tense, but Eide (2016: 150) does not view the 3PSg ending $-s$ as having a role in the tense system of PDE and regards this agreement marker as a "secondary accessory to finiteness" (Eide 2016: 150). Diachronically, the inflectional paradigm of English weak lexical verbs has thus collapsed into a syncretic system with one generalized [+Past] form and the bare form [-Past] that comprises the infinitive and the present (cf. Eide 2016: 147):

2 For Present-Day Danish, it should also be noted that when the last grapheme in the stem of a verb in Danish is $\langle\mathrm{r}\rangle$, the infinitive and the present tense form are homophonous,

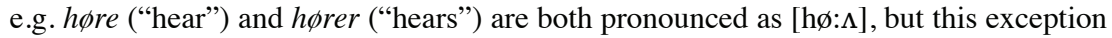
to the distinctions in finiteness is only relevant for a subset of verbs in Danish and is so limited that it does not threaten the productive morphological rule in Danish generating finite forms. 


\begin{tabular}{|l|l|}
\hline $\begin{array}{l}\text { +Past } \\
\text { Present-Day English: }\end{array}$ & $\begin{array}{l}\text { Preterit/Participle: } \\
\text { helped, healed }\end{array}$ \\
\hline $\begin{array}{l}\text { - Past } \\
\text { Present-Day English: }\end{array}$ & $\begin{array}{l}\text { Present/Infinitive: } \\
\text { help, heal }\end{array}$ \\
\hline
\end{tabular}

Even though they are not morphologically specified for finiteness, English main verbs can still encode the logophoric anchoring of the clause when they are the structurally highest verb (Eide 2016: 148-149).

The English auxiliaries are more complex: Modals and dummy do only occur in finite form, be has a morphological finiteness distinction, in contrast to have, which patterns with weak verbs (Eide 2016: 150). This fundamental difference in M-finiteness may have consequences for verb movement in PDE, as we will see next.

\subsection{Moving auxiliaries and main verbs}

Whereas verb movement ability is not tied to the status of a verb as either auxiliary or main verb in Danish and French (which might be related to a more or less uniform inflectional paradigm across these verb types), PDE has a split between auxiliaries on the one hand and main verbs on the other: Only finite auxiliaries can move out of $\mathrm{V}^{\circ}$ in English, aside from main verb $b e$. This exception cannot be explained with reference to morphology, as the inflectional paradigm (both in terms of agreement and M-finiteness) is identical for auxiliary be and main verb be. However, main verb be may be starting to follow in the way of the language change that main verb have has undergone in Standard English in terms of movement abilities (although there may be English variety differences): Searching for the string [I just was] in an exploratory sampling in the Corpus of Contemporary American English (COCA) and the British National Corpus (BNC) yielded 570 tokens in COCA (compared to 9382 tokens for the string [I was just]), and 23 in BNC (where [I was just] returned 1093 hits). This tells us that finite be may occur to the right of a sentence-medial adverb, presumably in $\mathrm{V}^{\circ}$, although it is far more frequently found to the left of "just", i.e. in $\mathrm{I}^{\circ}$. More interesting, however, is the distribution of auxiliary be and main verb be in the two strings (after having filtered out false starts, pauses, etc.): 


\begin{tabular}{|l|l|l|}
\hline BNC & Main verb be & Auxiliary be \\
\hline$[$ I just was $]$ & $55 \%(12 / 22)$ & $45 \%(10 / 22)$ \\
\hline$[$ I was just $]$ & $24 \%(242 / 1010)$ & $76 \%(768 / 1010)$ \\
\hline
\end{tabular}

Table 3: Distribution in BNC of main verb be and auxiliary be in $\mathrm{V}^{\circ}$ and $\mathrm{I}^{\circ}$.

\begin{tabular}{|l|l|l|}
\hline COCA & Main verb $b e$ & Auxiliary be \\
\hline [I just was $]$ & $59 \%(325 / 555)$ & $41 \%(230 / 555)$ \\
\hline
\end{tabular}

Table 4: Distribution in COCA of main verb be and auxiliary be in $\mathrm{V}^{\circ}$.

Looking exclusively at the results in $\mathrm{BNC}, 76 \%$ of the tokens with the string [I was just] represented auxiliary be, whereas $24 \%$ had main verb $b e$, which may suggest that auxiliary be is more frequent than main verb be overall. This would not be surprising, given that it is used for both the progressive aspect and the passive voice. However, the majority of the hits for [I just was] involved main verb be (55\% in BNC, and 59\% in COCA). Given the size of the sample, this may just be a coincidence. However, future research of a more rigorous nature may reveal whether these data alternatively signal that that main verb be is more inclined to stay in $\mathrm{V}^{\circ}$ than auxiliary $b e$, in which case we could be seeing the very beginning of a change in the syntactic abilities of main verb $b e$. This would presumably also spill over into its ability to move to $\mathrm{C}^{\circ}$ in V2-structures.

\subsection{M-finiteness and V2}

In the generative literature, $\mathrm{V}^{\circ}-\mathrm{I}^{\circ}-\mathrm{C}^{\circ}$-movement or $\mathrm{V} 2$ is generally assumed to be related to the WH-Criterion (Rizzi 1996), whereby the finite verb moves to $\mathrm{C}^{\circ}$ in order to enter into a Spec-head agreement configuration with the fronted element in CP-Spec. Vikner (1995: 64) argues that the trigger for $\mathrm{V} 2$ could be a particular feature in $\mathrm{C}^{\circ}$ (agreement, [+Finite] or $[+\mathrm{I}]$ ), which forces $\mathrm{C}^{\circ}$ to be filled (where possible fillers include both the feature $[+\mathrm{Wh}]$ and overt lexical material, e.g. a complementizer or a finite verb).

What is argued for in the present paper is that the relevant feature in $\mathrm{C}^{\circ}$ in V2-clauses is [+M-Finite], such that only the [+M-finite] verb can 
move there (cf. Eide 2016: 150-151). ${ }^{3}$ Even a main verb that is lexically marked as finite (e.g. the irregular verb went) by having a [+Past] and [+Finite] form may still be blocked from undergoing V2-movement, as the finiteness distinction on main verbs is no longer productive in PDE. Similarly, auxiliary have can move to $\mathrm{C}^{\circ}$ without encoding $[ \pm$ Finite] in its morphological paradigm. In other words, whether a verb possesses the M-finiteness feature relevant to syntactic movement is not necessarily directly visible from the overt markings on its lexical form, i.e. its "lexical finiteness" (or L-finiteness). This distinction, due to Eide (2016: 151), allows strong lexical verbs to be [+L-finite] but [-M-finite], as e.g. ablaut is no longer a productive morphological rule in the generation of verb forms. These "fossils of the long-dead rules" (Pinker 2000: 53), which are memorized, stand in opposition to the output of the productive morphological operation that just adds the suffix -ed (realized as [t], [d] or [Id], depending on the phonetic environment) for a [+Past] verb form. The split may even have reflexes in the neurobiology of language, $\mathrm{cf}$. Lely \& Pinker's (2014) division between the discrete neural networks underpinning Basic and Extended Morphology and Syntax.

Eide (2016: 152) speculates that there may be a causal chain, whereby the erosion of L-finiteness leads to the loss of productive M-finiteness for English main verbs. This has resulted in this category of verbs not having M-finiteness encoded, regardless of their L-finiteness, while the English auxiliaries, by Eide's stipulation, still have M-finiteness encoded. Danish and French, on the other hand, have inflectional suffixes that intrinsically link M-finiteness and L-finiteness in this analysis, and hence, all verbs are assumed to encode M-finiteness, as the productive morphological rule must refer to finiteness in the formation of verb forms.

\subsection{The loss of generalized V2 in English and French}

Eide (2016: 158) proposes that the relevant inflectional feature that caused the loss of V2 in English is M-finiteness and not the erosion of (a subset of)

3 There is an asymmetry between main clauses and embedded clauses in languages such as English, French and Danish, however, in that an embedded wh-clause does not trigger verb movement to $\mathrm{C}^{\circ}$. This asymmetry may be accounted for under the CP-recursion analysis proposed by Nyvad, Christensen \& Vikner (2017), which distinguishes between a "lexical" $\mathrm{CP}$, found in V2-clauses and thus conceivably requiring a [+M-finite] verb, and the "functional" $c \mathrm{P}$, hosting subordinating conjunctions. 
mood, agreement and/or tense inflections. Main verbs (but not auxiliaries and lexical be) in English have presumably lost the M-finiteness feature, while this is not the case in Danish or French, and this has consequences for verb movement in the three languages: Where all Danish main clauses require a $\left[+\mathrm{M}\right.$-finite] verb in $\mathrm{C}^{\circ}$, this is only the case for interrogative main clauses (and declaratives with negative topics in CP-Spec) in English and French, possibly as a result of the WH-Criterion (Rizzi 1996). French and English differ, however, in that all French verbs can move to $\mathrm{C}^{\circ}$ in the relevant structures, because they are [ $+\mathrm{M}$-finite], while only auxiliaries and main verb be have this feature in English (although main verb be may be starting to lose it, cf. section 2.2).

Pro-drop and V2 in combination within one language make the grammar "intrinsically unstable" (Yang 2000: 243), not least because null subject structures "punish" the V2 grammar in probabilistic terms, as this type of data may counter the linguistic evidence for verbs being in the second position. This is supported by Benincà (2006: 61), who claims that the V2 property was characteristic of many, perhaps even all, the Medieval Romance languages. Disregarding French, these were and still are prodrop languages and none of them are V2 today in their standard varieties. French lost its pro-drop property in the Middle French period, probably due to an impoverishment (homophony) in the inflectional paradigm, not found in the other Romance languages. Crucially, however, V2 was arguably lost before that: Yang (2000: 243) shows that pro-drop was still prevalent in $16^{\text {th }}$ century French when the preponderance of V2 had almost reached the Modern French level.

Thus, loss of V2 can seemingly occur for more than one reason: While English may have lost its V2 property due to erosion in morphological finiteness, French conceivably lost it due to another morphosyntactic factor: The rich inflectional system of Old French gave way to pro-drop, which in turn undermined the V2 system. Danish has not lost V2, as it is does not have null subjects (possibly due to the lack of person and number agreement morphology on its verbs) and it has productively retained the morphological finiteness distinction.

\subsection{M-finiteness and synchronic variation}

Another empirical observation that the collapse of the finiteness distinction [ \pm Finite] in the verbal paradigm of English may explain is the "preteritparticiple mix-ups" in irregular verbs (Eide 2016: 140). As Sampson 
(2002: 19) asserts, "[d]ialect usage frequently has the same form for past tense and past participle of an irregular verb which has distinct forms in the standard language", e.g. I should have went to the party or Peter gone to school. ${ }^{4}$

This phenomenon is "absolutely standard outside the upper and middle classes" in American English (Pinker 2000: 86) and it is found all over the English-speaking world (cf. features 130 and 131 in the Electronic World Atlas of Varieties of English). This suggests that its explanation is probably not sociolinguistic in nature, but should instead be found in the grammatical language system. Speakers thus appear to be trying to impose regularity in the inflectional system, aligning the irregular verbs with the regular paradigm, cf. Table 2 above:

\begin{tabular}{|l|l|l|}
\hline & +Finite & -Finite \\
\hline $\begin{array}{l}\text { +Past } \\
\text { Modern English }\end{array}$ & Preterit: & Participle: \\
went, saw drove & gone, seen, driven \\
\hline -Past & Present: & Infinitive: \\
Modern English & go, see, drive & go, see, drive \\
\hline
\end{tabular}

Table 5: The irregular verbs in Standard English (adopted from Eide 2016: 248)

\begin{tabular}{|l|l|}
\hline $\begin{array}{l}\text { +Past } \\
\text { Non-standard English }\end{array}$ & $\begin{array}{l}\text { Preterit/participle: } \\
\text { gone, seen, drove }\end{array}$ \\
\hline -Past & Present/infinitive: \\
Non-standard English & go, see, drive \\
\hline
\end{tabular}

Table 6: Leveling of irregular verbs in some English vernaculars (adopted from Eide 2016: 248)

The collapsed paradigm in Table 2 illustrates what the productive paradigm of regular verbs in English has been like for centuries, but irregular strong verbs in Standard English have conserved [ \pm Finite], as the preterit and the participle have distinct forms. However, this finiteness distinction is undergoing morphological leveling in many English vernaculars, such that the preterit and the participle become syncretic and hence align with the system of the regular verbs, retaining [ \pm Past] and losing [ \pm Finite]

4 The leveling of the past tense/past participle verbs forms may thus result from the preterit replacing the past participle or vice versa, but what is of principal importance for the analysis presented here is that only irregular verbs are subjected to this type of leveling because they, unlike regular verbs, maintain an M-finiteness distinction. 
(Eide 2016: 159-160). In OE, there were at least 325 strong verbs, and according to Pinker (2000: 89), PDE has approximately "164 irregular verbs: 81 weak (ending in $t$ or $d$ ), 83 strong [i.e. with ablaut]". Only these strong verbs distinguish the preterit and the participle (the present and the infinitive are identical), and very few verbs thus overtly encode finiteness morphologically in PDE. Language-acquiring children very often overgeneralize the productive morphological rule and inflect their preterits according to the regular paradigm, and over time, the remaining irregular verbs will probably gradually defect from their paradigms and align with the collapsed paradigm in Table 6 in adult speakers as well.

If the specific type of paradigmatic leveling taking place in English and its consequent lack of $\mathrm{M}$-finiteness is indeed the cause of this phenomenon, that would explain why we do not find it in languages such as Danish or French, which have retained a productive morphological rule generating a finiteness distinction, and hence the computational system would not be prone to muddling up the two [+Past] forms.

\section{M-finiteness in language acquisition}

According to Holmberg \& Roberts (2013: 112), children are "highly sensitive to morphology, particularly inflectional morphology", and it may thus represent a significant cue in the acquisition of syntax. In this section, it will be argued that the lack of a productive M-finiteness distinction in English described above also generates an exceptional pattern found in English-speaking children's early interrogative structures.

\subsection{The distribution of finite and non-finite clauses}

In typical language development, a child acquiring a Germanic language like English or Danish will generally go through a phrase around the age of two where she produces both finite and non-finite root clauses, known as the Optional Infinitive (Wexler 1999) or Root Infinitive (Rizzi 1993) phase. Hamann \& Plunkett (1998) observed two Danish-speaking children, Anne and Jens, from the age of one to six. They found that they did not start by producing infinitives. In fact, finite clauses comprised the majority of their utterances from the very start: 
(11) Finite
a. Det lukker
It close-PRES
b. Her er koppen Here is cup.DE
c. Det gider ikke That want-PRES not

\section{(12) Non-finite ${ }^{5}$}
a. $\mathrm{Du}$ tegne
You draw-INF
(Anne 1;7,18)

b. Køre bil (Anne 1;8,22)

Drive-INF car

c. Nej, ikke have (Jens 1;10,14)

No, not have-INF

However, the acquisition of English strikingly stands out: While the production of non-finite main clauses extends to wh-questions in Englishspeaking children, non-finite $w h$-questions and topicalization structures are virtually absent in child data from Germanic V2-languages, such as Danish. The two Danish-speaking children from Hamann \& Plunkett's (1998) study almost exclusively produced finite wh-questions $(1.5 \%$ and $4.7 \%$ non-finite, respectively), while around a fourth of their utterances overall were non-finite $(27.4 \%$ and $23.6 \%) .{ }^{6}$ The English data presented here are from the Brown corpus (Brown 1973) and the Manchester corpus (Theakston et al. 2001) in the CHILDES database (MacWhinney 2000), cited by Westergaard (2016: 267-268):

\section{(13) Non-finite}
a. What he doing?
b. Where my spoon gone?
c. Where me sit?
d. Why you get another one?
e. What you looking for?

(Adam 3;0.11)

(Warren 2;0.17)

(Anne 2;3.28)

(Liz 2;8.14)

(Ruth 2;7.24)

5 Note that while the verb in (12a) is unambiguously non-finite (the pronunciation of tegne, ['tajnə], is different from the finite form tegner, ['tajn $\Lambda$ ]), the transcriber must have had another reason for categorizing the verb køre in (12b) as non-finite, given that the finite and the non-finite forms are homophonous here ([kø: $\Lambda])$, because the last grapheme in the stem is $\langle\mathrm{r}\rangle$, cf. section 2.3 above.

6 As for the acquisition of French, Crisma (1992) reports that approximately $20 \%$ of the declarative main clauses in French-speaking Philippe's sample in CHILDES (Suppes, Smith \& Leveillé 1973) are non-finite, while his wh-questions were all finite, and this pattern is replicated in three other corpora examined by Phillips (1995). 
Functional elements are generally acquired relatively late (Westergaard 2016: 259), so it is not surprising that English-speaking children tend to omit auxiliaries for quite a while, as illustrated in (13). However, when they are present in child data, they tend to be target-consistently inverted with the subject. Rizzi (1993) argues that when CP-spec is filled by a wh-element, consequently projecting a CP-layer, the lower projection IP, containing finiteness, cannot be truncated. Hence, whereas non-finite root clauses are VPs, finite $w h$-questions are CPs. The data in (13) may thus be explained with reference to a late setting of the V2 parameter, which requires a finite verb in $\mathrm{C}^{\circ}$ (cf. Wexler 1999). In a similar vein, Clahsen (1986) asserts that the mastery of verbal inflections and in particular agreement marking is a developmental prerequisite for the acquisition of V2 in German. However, Clahsen \& Penke (1992: 215) concede that, given the lack of agreement marking in the Mainland Scandinavian languages, this causal relationship cannot apply universally. As opposed to agreement marking, it will be argued in the following section that the notion of M-finiteness is of primary importance in the acquisition of verb movement to $\mathrm{C}^{\circ}$ in English, Danish and French.

\subsection{A possible explanation for the cross-linguistic variation based on M-finiteness}

What separates the productions of English-, French-, and Danish-speaking children is simply the propensity to move a verb to $\mathrm{C}^{\circ}$ in $w h$-questions and topicalized structures, which may be due to $\mathrm{M}$-finiteness being encoded for all verbs in the grammars of Danish and French, but not in that of English. If there is a [+M-finite] feature in $\mathrm{C}^{\circ}$, this would force any verb that moves there to be spelt out as finite. The verb picks up the finiteness inflection in $\mathrm{I}^{\circ}$ on its way to $\mathrm{C}^{\circ}$, so it is not surprising that children produce finite clauses when the verb is in $\mathrm{C}^{\circ}$. When the verb is in $\mathrm{V}^{\circ}$ (which has not merged with the inflectional features in $\mathrm{I}^{\circ}$ ), it should be non-finite (the default infinitive form), which is also what we see cross-linguistically. In English, there appears to be a phase where the $[+\mathrm{M}$-finite $]$ feature in $\mathrm{C}^{\circ}$ in $w h$-structures can be left unrealized, not unlike English subject questions which do not have subject-auxiliary inversion and allow a main verb to stay finite in $\mathrm{V}^{\circ}$. If we assume that subject questions in English are IPs and not CPs, this is explained, as no $\mathrm{C}^{\circ}$ requiring a [ $+\mathrm{M}$-finite] verb is projected. The noise in the system engendered by syncretism in the verbal forms in English (blurring the finiteness distinction), compounded by the fact that only auxiliaries 
and main verb be can move to $\mathrm{C}^{\circ}$, may delay the acquisition of $\mathrm{V}^{\circ}-\mathrm{I}^{\circ}-\mathrm{C}^{\circ}-$ movement in English. In other words, the non-finite wh-clauses in child English may well be the expression of a problem in the implementation of their morphological, not necessarily syntactic, knowledge. ${ }^{7}$

This leaves us with another question: Why are clauses without whmovement to CP-Spec not obligatorily finite in the child grammars of V2languages like Danish? That is, why doesn't $\mathrm{C}^{\circ}$ demand a [+M-finite] verb in subject-initial declarative clauses? The answer appears to be that language-acquiring children may optionally truncate functional projections (cf. Rizzi's 1993 truncation model above), because their grammar lacks an axiom, which is not acquired until around the age of two and a half years, namely that a root clause is a CP. A non-subject fronted constituent (a whelement or a topic) must, however, activate a CP-layer which then selects the IP-projection below it. A sentence-initial subject does not have this effect.

The proportion of non-finite root clauses is reduced very gradually (Phillips 1995: 8), which aligns with the basic tenets of Yang's (2000) variational model. He views language acquisition as "a variational process in which the distribution of grammars changes as an adaptive response to the linguistic evidence in the environment" (Yang 2000: 234). This may account for differences found between English, Danish, and French: The lack of correspondence between L-finiteness and M-finiteness in English (see section 2.3) might pose a problem in language acquisition. Compared to Danish- and French-speaking children, a child acquiring English will have a delay in the acquisition of the syntactic requirement that $\mathrm{C}^{\circ}$ needs to be filled by a [+M-finite] verb: Whereas Danish- and French-speaking children have plenty of positive evidence for the syntactic behavior of verbs in main clause questions, as the finite verb in $\mathrm{C}^{\circ}$ in all the relevant structures is [+M-finite], English-speaking children are not aided by morphology, due to widespread syncretism in the main verbs and irregularities in their auxiliaries. It thus takes longer to converge on that setting.

One theoretical, albeit unfeasible, way to substantiate the claim that the syncretisms in the verbal paradigm of English influence the acquisition of finite $w h$-questions would be to analyze language acquisition data from the $\mathrm{OE}$ and Early ME periods. All verbs were $[ \pm \mathrm{M}$-finite] at these earlier

7 However, given the syncretic verb forms in English, it is not even clear that the verbs in the productions of English-speaking children are root infinitives to the extent reported; a large proportion of them could in principle be bare stems (present tense forms without agreement marking). 
stages of English and we would thus expect the child wh-question productions at this time to pattern with Present-Day Germanic V2-languages in being finite.

\section{Conclusion}

In this paper, Eide's (2016) interpretation of morphological finiteness was explored in connection with V2-structures in English, Danish, and French, and it was applied to syntactic facts in diachrony, language variation and language acquisition. The data presented support the view that the syncretism resulting from a collapse in the $\left[{ }_{ \pm}\right.$Finite] distinction in English may have had a role to play in all three areas. While the Rich Agreement Hypothesis proposed for $\mathrm{V}^{\circ}$-to- $\mathrm{I}^{\circ}$ movement by e.g. Vikner $(1997,1999)$ is not able to account for the patterns observed in relation to V2-movement, it may thus be that a weaker version based on finiteness morphology has that potential, as both language-internal and cross-linguistic patterns in verb movement to $\mathrm{C}^{\circ}$ (or lack thereof) can receive a unified account within such a framework.

The types of variation found are not surprising: Exposed to positive evidence, a child slowly converges on her target grammar, while non-target grammars are accessed in the process through probabilistic mechanisms that may result in the non-uniformity observed in child data. This situation is similar to the co-existence of multiple grammars, prompted by the heterogeneity introduced by e.g. the steady erosion of inflectional paradigms or the optional application of V2, witnessed in e.g. historical texts. These reflect varying internal representations of positive linguistic data and they are the very basis of language change.

\section{References}

Benincà, Paola. 2006. A detailed map of the left periphery of Medival Romance. In Raffaella Zanuttini, Héctor Campos, Elena Herburger \& Paul Portner (eds.), Crosslinguistic research in syntax and semantics: negation, tense, and clausal architecture, 53-86. Washington DC: Georgetown University Press.

Bertelsen, Henrik. 1905. Dansk sproghistorisk laesebog, første del: Oldtid og middelalder (400-1500), I. Tekster og sproghistoriske oversigter. Copenhagen: Nordisk Forlag. 
Bobaljik, Jonathan David \& Höskuldur Thrainsson. 1998. Two heads aren't always better than one. Syntax 1.1.37-71. doi:10.1111/1467-9612.00003.

Brown, Roger. 1973. A first language: The early stages. Cambridge, MA: Harvard University.

Brøndum-Nielsen, Johs. 1974. Gammeldansk grammatik VIII. Copenhagen: Akademisk Forlag.

Chomsky, Noam. 1957. Syntactic structures. The Hague: Mouton.

Clahsen, Harald. 1986. Verb inflections in German child language: acquisition of agreement markings and the functions they encode. Linguistics 24. 79-121. doi:10.1515/ling.1986.24.1.79.

Clahsen, Harald. \& Marina Penke. 1992. The acquisition of agreement morphology and its syntactic consequences: new evidence on German child language from the Simone-corpus. In Jürgen Meisel (ed.), The acquisition of verb placement: Functional categories and V2 phenomena in language acquisition, 181-223. Dordrecht: Kluwer.

Crisma, Peter. 1992. On the acquisition of wh-questions in French. Geneva Generative Papers. 115-122.

Davies, Mark. (2004-) British national corpus (from Oxford University Press). Available online at https://www.english-corpora.org/bnc/.

Davies, Mark. (2008-) The corpus of contemporary American English (COCA): 560 million words, 1990-present. Available online at https://www.englishcorpora.org/coca/.

Davis, Norman O. (ed.) 1971. Paston letters and papers of the fifteenth century (2 vols.). Oxford: Clarendon.

Eide, Kristin Melum. 2016. Finiteness, inflection, and the syntax your morphology can afford. In Kristin Melum Eide (ed.), Finiteness matters: On finitenessrelated phenomena in natural languages (Linguistik Aktuell/Linguistics Today 231), 121-168. Amsterdam: John Benjamins Publishing Company. doi:10.1075/ la.231.05eid.

Garbacz, Piotr. 2010. Word order in Övdalian: a study in variation and change. Lund University $\mathrm{PhD}$ dissertation.

Gelderen, Elly van. 2006. A history of the English language. Amsterdam: John Benjamins Publishing Company.

Hamann, Cornelia \& Kim Plunkett. 1998. Subject sentences in child Danish. Cognition 69. 35-72.

Holmberg, Anders \& Ian Roberts. 2013. The syntax-morphology relation. Lingua 130. 111-131. doi:10.1016/j.lingua.2012.10.006.

Kortmann, Bernd \& Kerstin Lunkenheimer (eds.) 2013. The electronic world atlas of varieties of English. Leipzig: Max Planck Institute for Evolutionary Anthropology. (Available online at http://ewave-atlas.org)

Lasser, Ingeborg. 1997. Finiteness in adult and child language. City University of New York doctoral dissertation. 
Lemieux, Monique \& Fernande Dupuis. 1995. The locus of verb movement in non-asymmetric verb second languages: the case of Middle French. In Adrian Battye \& Ian Roberts (eds.), Clause structure and language change (Oxford Studies in Comparative Syntax). 80-109. New York: Oxford University Press.

Lely, Heather K. J. van der \& Steven Pinker. 2014. The biological basis of language: insight from developmental grammatical impairments. Trends in Cognitive Sciences 18(11). 586-595. doi:10.1016/j.tics.2014.07.001.

Lightfoot, David. 2006. How new languages emerge. Cambridge: Cambridge University Press.

MacWhinney, Brian. 2000. The CHILDES Project: Tools for analyzing talk, vol. 2: The database. 3rd edn. Mahwah, NJ: Lawrence Erlbaum.

McWhorter, John. 2005. Defining creole. Oxford: Oxford University Press.

Nyvad, Anne Mette, Ken Ramshøj Christensen \& Sten Vikner. 2017. CPrecursion in Danish: A cP/CP-analysis. The Linguistic Review 34(3). 449-477. doi:10.1515/tlr-2017-0008.

Phillips, Colin. 1995. Syntax at age two: Crosslinguistic differences. In Carson T. Schütze, Jennfier B. Ganger \& Kevin Broihier (eds.), Papers on language processing and acquisition, MIT Working Papers in Linguistics 26. 325-382.

Pinker, Steven. 2000. Words and rules. The ingredients of language. London: Phoenix.

Rizzi, Luigi. 1993. Some Notes on linguistic theory and language development: The case of root infinitives. Language Acquisition 3(4). 371-393. doi:10.1207/ s153278171a0304_2.

Rizzi, Luigi. 1996. Residual verb second and the wh-criterion. In Adriana Belletti \& Luigi Rizzi (eds.), Parameters and functional heads. Oxford: Oxford University Press.

Roberts, Ian. 1993. Verbs and diachronic syntax. Dortrecht: Kluwer.

Roberts, Ian. 2007. Diachronic syntax. Oxford: Oxford University Press.

Rohrbacher, Bernard. 1999. Morphology-driven syntax. Amsterdam: John Benjamins.

Schwartz, Bonnie \& Sten Vikner. 1996. The verb always leaves IP in V2 clauses. In Luigi Rizzi \& Adriana Belletti (eds.), Parameters and functional heads: essays in comparative syntax, 11-62. Oxford: Oxford University Press.

Suppes, Patrick, Roy Smith \& Madeline Leveillé. 1973. The French syntax of a child's noun phrases: Archives de Psychologie 42. 207-279.

Theakson, Anna L., Elena V.M. Lieven, Julian M. Pine \& Caroline F. Rowland. 2001. The role of performance limitations in the acquisition of verb-argument structure: An alternative account. Journal of Child Language 28. 127-152.

Vikner, Sten. 1995. Verb movement and expletive subjects in the Germanic languages. New York: Oxford University Press.

Vikner, Sten. 1997. $\mathrm{V}^{\circ}$-to- $\mathrm{I}^{\circ}$ movement and inflection for person in all tenses. In Liliane Haegeman (ed.), The new comparative syntax, 189-213. London: Longman. 
Vikner, Sten. $1999 . \mathrm{V}^{\circ}$-til-I ${ }^{\circ}$ flytning og personfleksion i alle tempora. Islenskt mál 19. $81-128$.

Vikner, Sten. 2004. Det finitte verbums position i dansk før og nu. In Peter Widell \& Mette Kunøe (eds.), 10. Møde om Udforskningen af Dansk Sprog, 383-394. Aarhus: Nordic Department, Aarhus University.

Westergaard, Marit. 2016. Word order and finiteness in acquisition: A study of Norwegian and English Wh -questions. In Kristin Melum Eide (ed.), Finiteness matters: On finiteness-related phenomena in natural languages (Linguistik Aktuell/Linguistics Today 231), 257-286. Amsterdam: John Benjamins Publishing Company. doi:10.1075/la.231.09wes.

Wexler, Ken. 1994. Optional infinitives, Head movement and the economy of derivations in child grammar. In Norbert Hornstein \& David Lightfoot (eds.), Verb movement, 305-350. Cambridge: Cambridge University Press.

Wexler, Ken. 1999. Innateness of language. In Robert A. Wilson \& Frank C. Keil (eds.), The MIT Encyclopedia of the Cognitive Sciences. Cambridge, MA: MIT Press.

Wiklund, Anna-Lena, Gunnar Hrafn Hrafnbjargarson, Kristine Bentzen \& porbjörg Hróarsdóttir. 2007. Rethinking Scandinavian verb movement. The Journal of Comparative Germanic Linguistics 10(3). 203-233. doi:10.1007/ s10828-007-9014-9.

Yang, Charles D. 2000. Internal and external forces in language change. Language Variation and Change 12(3). 231-250. doi:10.1017/S0954394500123014. 